ISSN: 1641-4713; e-ISSN: 2081-1160

DOI: https://doi.org/10.36551/2081-1160.2021.95-110

\title{
Civil resistance against military dictatorships: People power in Bolivia
}

\author{
Resistencia civil contra las dictaduras militares: El poder popular \\ en Bolivia
}

Reynaldo Tapia

John Jay College of Criminal Justice, United States ORCID iD: https://orcid.org/0000-0002-9662-1551

E-mail: rtapia@jjay.cuny.edu

Recepción: 27.06.2021

Aprobación: 9.12.2021

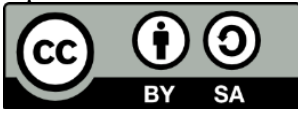

\begin{abstract}
Civil resistance has had a crucial role in promoting social, political, and economic change throughout the world. During the period of dictatorships in South America, civil resistance through the use of nonviolent methods was implemented by Las Madres de la Plaza de Mayo (Mothers of the Plaza de Mayo) to address human rights violations, which eventually led to campaigns to demand democracy in Argentina. The military dictatorship of Pinochet in Chile also fell to the nonviolent campaigns and people power movements. Bolivia presents another case on the effectiveness of civil resistance against not only military dictatorships but also to demand the comeback of democracy. This article examines how civil resistance was implemented in Bolivia during the period of military dictatorships from 1964 to 1982 . Once in power, the military dictatorships began to target workers and their union leaders, student organizations and leftist politicians driving them underground and into exile. State violence was used to repress opposition groups from all sectors and even the press. Security forces to include paramilitary groups were behind a series of kidnappings, tortures and killing of activists. To curb the state violence, union workers, miners, indigenous/campesino group, political leaders, and university students began a series of coordinated nonviolent methods, such as hunger strikes, road blockades, mass protests and marches. This article describes the benefits and outcomes of civil resistance showing how these nonviolent techniques and strategies were used to fight against military dictatorships and led the country back onto the path of re-democratization.
\end{abstract}


Keywords: civil resistance, nonviolent action, military dictatorships, re-democratization, people power

Resumen: La resistencia civil ha tenido un papel crucial en la promoción del cambio social, político y económico en todo el mundo. Durante el período de las dictaduras en Sudamérica, Las Madres de la Plaza de Mayo implementaron la resistencia civil a través del uso de métodos noviolentos para abordar las violaciones de los derechos humanos, lo que eventualmente llevó a campañas para exigir la democracia en Argentina. La dictadura militar de Pinochet en Chile también cayó ante las campañas noviolentas y los movimientos de poder popular. Bolivia presenta otro caso sobre la efectividad de la resistencia civil no solo contra las dictaduras militares sino también para exigir la restitución de la democracia. Este artículo examina cómo se implementó la resistencia civil en Bolivia durante el período de las dictaduras militares de 1964 a 1982. Una vez en el poder, las dictaduras militares comenzaron a atacar a los trabajadores y sus líderes sindicales, organizaciones estudiantiles y políticos de izquierda, empujándolos a la clandestinidad y al exilio. Se utilizó la violencia estatal para reprimir a los grupos opositores de todos los sectores e incluso a la prensa. Las fuerzas de seguridad, incluyendo grupos paramilitares, estuvieron detrás de una serie de secuestros, torturas y asesinatos de activistas. Para contrarrestar la violencia estatal, los trabajadores sindicales, mineros, grupos indígenas/campesinos, líderes políticos y estudiantes universitarios comenzaron una serie de métodos coordinados y noviolentos, como huelgas de hambre, bloqueos de carreteras, protestas masivas y marchas. Este artículo describe los beneficios y resultados de la resistencia civil y detallará cómo estas técnicas y estrategias noviolentas se utilizaron para luchar contra las dictaduras militares y llevaron al país de regreso al camino de la redemocratización.

Palabras clave: resistencia civil, acción noviolenta, dictaduras militares, redemocratización, poder popular

\section{INTRODUCTION}

The Bolivian National Revolution of April 1952 did not only terminate the oligarchic control of the country but tremendously weakened the Bolivian Armed Forces. The military institutions were demoralized due to their defeat at the hand of some workers and MNR militants. President Paz Estenssoro understood that armed workers would jeopardize his political stability and began to slowly reorganize the Bolivian Armed Forces and re-opened the military academy. Paz Estenssoro mistrusted the labor-left's armed power and after the 1956 MNR Convention, dominated by leftist militants, he went with his vice-president, Siles Zuazo, to the U.S. embassy to ask for assistance in rebuilding the Bolivian military as a counterbalance to the militias (Lehman, 1999, p. 148). Paz Estenssoro believed he could manage the army, gain their loyalty and use them for his political objectives.

After twelve years, the social-political momentum of the Bolivian National Revolution would come to an end on November 4, 1964 when Paz Estenssoro was ousted in a military coup by his own vice-president, General Rene Barrientos. Barrientos would set the country in a period of violent instability 
under various military administrations. The people of Bolivia challenged the military regimes using both violent and nonviolent forms of resistance but met with brutal state repression. Coalitions of old and new groups began implementing various methods of civil resistance as the number of participants in people power grew larger and larger. This article addresses the way civil resistance was used against the brutal repression and state violence of Bolivian military dictatorships. Due to the profound focus on cases of violent repression endured by the Bolivian people, Bolivian episodes of people power have been overlooked, even though the country has a history of resistance including episodes of civil resistance. Civil resistance is also referred to as nonviolent resistance and nonviolent action since they describe the same phenomenon. Civil resistance is defined as organized popular challenges to authoritarian rule and/or democratic governments by the primary use of nonviolent methods rather than violent actions (Schock, 2005; Zunes, 1994). Other scholars have also argued that rather than violent forms of popular resistance, civil resistance is more in line when it comes to replacing authoritarian governments and demanding for a fair democratic process (Carter, 2012). Civil resistance has in numerous instances contradicted the nostalgic belief that an armed revolution led by charismatic guerrilla fighters will liberate people from oppression.

To have a better understanding of the effectiveness of civil resistance in Bolivia's age of dictatorships, it is crucial to understand how these strategies and tactics were used to destabilize the power of the oppressors. Gene Sharp, a leading expert in nonviolent methods, has identified hundreds of nonviolent techniques which include protests, boycotts, and civil disobedience, all aimed at waging conflict through social, economic, and political means without the use of violence. Sharp (1990) describes civil resistance as a way of combat because of its use of strategies and tactics, and because it demands of its soldiers: courage, discipline, and sacrifice when they wage battles. The people of Bolivia were well disciplined in not only maintaining nonviolent order but also in creating and adopting new strategies of civil resistance. Nonviolent techniques like hunger strikes, protests, roadblocks, pilgrimages, and marches resulted in the mass arrest of activists, which was their goal in order to capture the attention of the national media. People power also describes these struggles which are civilian-based and carried out through widespread popular participation (Schock, 2005).

A critical element for the success of civil resistance is the process of backfire. As explained by Martin (2007), backfire is an action that recoils against its originators leading to a negative consequence, namely worse than having done nothing. Sharp refers to this phenomenon as "political jiu-jitsu" where the force 
or power of the oppressor is used against him or her. This article will contribute to the study of civil resistance as it explores the effectiveness of nonviolent resistance in Bolivia during its age of military dictators. Most importantly, this article explains the outcomes of civil resistance by highlighting the strategies that were developed by the poorest people in Latin America to counter repressive military regimes. This article also proposes that the civil resistance was not only successful in challenging military dictators but also contributed to the re-democratization of the country.

\section{METHODOLOGY}

To explain the implementation and outcomes of civil resistance in Bolivia during its military dictatorships this research used the comparative historical analysis method. The article presents chronologically the implementation of civil resistance in Bolivia by providing descriptive narratives of several events, thus allowing for a holistic analysis which considers context, conjuncture, and sequence. The analysis of the largely descriptive historical narratives will be used to address the article's two main questions: (1) How was civil resistance implemented in Bolivia? and (2) How did civil resistance lead to the re-democratization of the country?

The study compares how several forms of civil resistance were used during different military regimes in Bolivia. The choice of the comparative method in the field of social movements and resistance is often justified by its capacity to go beyond statistical measures and more towards an in-depth understanding of historical processes (Della Porta, 2002). In order to analyze the outcome of these civil resistance campaigns in Bolivia the study is divided into three dictatorship periods: (1) the Barrientos dictatorship: the San Juan Massacre, and the failures of armed insurgencies; (2) the Banzer dictatorship: the Tolata Massacre and the hunger strike, and (3) the García Meza dictatorship: the coup d'état and the fight for democracy.

The article tries to develop a comparative framework of different episodes of civil resistance in Bolivia by analyzing these three dictatorships through a methodological approach which attempts to identify the major outcomes and their contribution to the re-democratization of Bolivia. As noted by Tilly (1984), this method is not a bungled attempt at generalization but seeks to find variations that highlights the uniqueness of social phenomena. Rather than testing a hypothesis, the purpose of this method is to find patterns that explain the social and political impact of civil resistance in Bolivia. 


\section{The Barrientos' dictatorship: The San Juan Massacre and the failure of armed insurgencies}

The November 1964 Barrientos coup that ousted Paz Estenssoro ended the MNR controlled state (1952), thus ending the National Revolution and establishing an era of military dictatorships that would last until 1982. The army became an armed political party as the military leaders assumed important political posts at a local, provincial and national level (Malloy \& Gamarra 1988). Barrientos was a native of Cochabamba who spoke Quechua and his charisma attracted the loyalty of the various campesinos (peasant) groups of his region. However, Barrientos was actually weakening campesino organizations and discouraging popular election of campesino leaders at all levels while directly financing their support for the Pacto Militar-Campesino (Mitchell, 1977). The infamous Military-Campesino Pact reassured the Bolivian Armed Forces' commitment to the defense of the agrarian reform of the National Revolution as long as the campesinos supported the government and obeyed military orders, acting against the subversive maneuvers of the left.

The approach of Barrientos towards urban labor and miner unions in general was markedly different from his handling of the country's rural unions and the campesinos groups. Within the first few months of his administration, Barrientos began to demonstrate implacable hostility towards leftist politicians and unions. The miners armed themselves and declared key mining camps "free territories" after Barrientos claimed that the FSTMB led by Lechin was planning a communist rebellion (Mitchell, 1977). By May of 1965, the Barrientos administration removed the leaders of the COB, FSTMB and forced all unions to reorganize under an apolitical labor movement controlled by the government. The FSTMB tried to recover its position by declaring a general strike in the mines, but in response the army invaded the encampments of several mining centers and began arresting the labor leaders (Nash, 1979). Workers from all sectors began to organize civil resistance campaigns in the form of strikes. Ad hoc committees of miners, factory and construction workers, teachers and cooks failed after the mining centers were bombed and hundreds of activists were sacked (Roddick \& van Niekerk, 1989). Morality among workers and miners was low since their leadership was targeted, and their wages were either cut or stagnate. Despite the persecution, the mining leadership went on with their plans for a meeting on June 24, 1967, during the San Juan holiday. The union meeting was targeted by the ranger regiment and police which had already surrounded the district of the Catavi and Siglo XX mines before dawn (Delgado González, 1984). The event that occurred 
that morning would become known as the "San Juan Massacre." The military came with machine guns, mortars and hand grenades, and began shooting at people who were still dancing on the streets; they fired at houses while their occupants were sleeping, with the intention to break resistance and demoralize any revolutionary spirit (Nash, 1979). The military was ruthless and did not discriminate in targeting also women and children, resulting in the death of 87 people (Roddick \& van Niekerk, 1989). Soldiers were forced to shoot at innocent miners and their relatives who were among the residents. More than ten soldiers were executed for disobeying firing orders since they were from that area and their family members were in the crowds (Viezzer, 1978). A general strike was called in to protest against the San Juan Massacre events. It lasted sixteen days, but the strike committee finally decided to negotiate with the government, accepting an extremely humiliating agreement to end the conflict (Alexander, 2005). The message was clear and precise; enemies of the regime would be severely punished. According to Alexander (2005), this was also a tip to a national miners' meeting in Huanuni if they should aid Che Guevara's guerrillas with food and medicine.

The popularity of Fidel Castro and Ernesto "Che" Guevara was of great concern to the Bolivian government, since the Cuban Revolution demonstrated that social change could be achieved through armed struggle. On November 3, 1966, "Che" Guevara came to Bolivia and set up his camp in Nancahuazu to form the National Liberation Army (ELN). By mid-1967 the Barrientos security forces were cracking down on groups that might communicate with the guerrilla insurgency. By August 1967, Che's insurgency had lost several guerrilla fighters in a skirmish with the Bolivian army. The ELN was on the run, demoralized and without any food. As detailed in his diary in Bolivia, Guevara was frustrated that he was unable to recruit any campesino to join his guerilla: "The characteristics of the month are the same as those of the previous one, except that the army is now showing more effectiveness in action. In addition, the mass of peasants (campesinos) are not helping us at all and are being turned into informants" (Guevara, 1994, p. 289). By early October, Guevara's small guerrilla was defeated by the Bolivian army with the assistance of the CIA and U.S. Special Forces. The injured Che was captured and later executed in a school in the small town of La Higuera. At no stage during the campaign did local campesinos join the guerrilla forces, although many were willing to sell them food at a high cost and most of them sold them out to the military (Dunkerley, 1984).

The attempt to initiate an armed revolution in Bolivia failed partly because most of the campesino masses did not join or cooperate with the ELN guerrilla since most of them owned their land and were not dissatisfied with the state 
but actually supported Barrientos. But not all campesino organizations were blindly loyal to Barrientos or agreed to the terms of the Military-Campesino Pact. While Barrientos was popular among the campesinos of Cochabamba who spoke Quechua he was unable to gain the support of Aymara speaking campesinos. The rejection of these communities towards his regime grew due to the fiscal project called "impuesto único" or "only tax." Under the advisement of USAID and the University of Wisconsin, Barrientos tried to impose a fiscal reform requiring campesinos to pay a tax on their land, but it provoked numerous protests (Rivera Cusicanqui, 1984). Demonstrations and rural conflicts divided campesinos between those who rejected the tax and those who remained loyal to Barrientos and supported the impuesto único decree (Lavaud, 1986). In Achacachi in December 1968 Barrientos encountered 2,000 to 3,000 campesinos who began to boo and heckle his speech forcing his security to shoot tear gas at the crowds (Lavaud, 1986). The town had to be placed under military control once the campesino residents began throwing rocks at the president and his entourage (Rojas Ramírez, 1989). The mobilization of civil resistance campaigns was promoted by the Bloque Independiente Campesino which was headed by the leftist and Pro-Lechín members of the MNR (Rivera Cusicanqui, 1984). By the end of December, the Independent Block of Campesinos of La Paz signed an alliance with the workers and university students to oppose the Military-Campesino alliance (Lavaud, 1986). Four months later, in April of 1969, General Barrientos died when his helicopter crashed while inaugurating a school in a small town in Cochabamba.

\section{The Banzer dictatorship: Tolata Massacre and the hunger strike}

The civilian government of Barrientos'vice-president, Adolfo Siles Salinas, only lasted five months until it was overtaken by General Ovando. Ovando's short regime would be highly criticized for the brutal mishandling of the newly formed ELN guerrilla group composed of mostly university students. By 1970, the ELN initiated their guerrilla operation in the Teoponte region located in the Yungas tropical jungles. The growing reports of military execution of ELN members led to public support for the families of the guerrillas and provoked a nationwide hunger strike of hundreds of university students, workers and some clergy demanding the names and bodies of the ELN members that were killed by the military (Payne, 2012). The military regime was being pressured by several social and political groups to release the information it was trying so hard to hide. Finally, by late September, Ovando turned in some of the bodies that had been destroyed by Bolivian military using bazookas and hand grenades (Nash, 
1979). By October 1970 Ovando was replaced by General Juan Jose Torres. Torres proved to be the most radical and left-leaning military ever to have govern Bolivia by extending the mobilization of militant workers and leftist politicians while carrying an extremely pro-worker and anti-imperialist agenda (Klein, 2003). Torres had survived a coup in January which was executed by Coronel Hugo Banzer but was unable to prevent his second attempt.

On August 22 $2^{\text {nd }}, 1971$, Coronel Hugo Banzer Suarez rose to power and began one of the darkest episodes in Bolivian history. The miners, union leaders, students and leftist parties were unprepared for Banzer's right wing uprising. The tone was set when Banzer ordered an assault at the San Andres University where pro-Torres students had taken refuge. Air force fighter planes flew around the building as infantry troops entered killing several students while arresting and interrogating the rest (Mitchell, 1977). Banzer later shut down universities and suspended all COB and FSTBM activities. Freedom of press was strictly censured during his regime, and in the absence of any formal or informal control he was able to persecute, imprison, exile and kill all opposition to his government, who were mostly leftist party members and supporters. Quiroga Santa Cruz (1973) points out that the Banzer regime's goal was the elimination of the revolutionary left, the extermination of its vanguard and the suppression of the university student movement. Hahn (1992) adds that a least 200 people were killed, not including the ones that died during his coup; some 14,750 were jailed for state offenders, 19,140 were forced to exile and some 780,000 people became economic refugees.

In January 1974, Banzer proposed an austerity package that doubled most food prices. Civil resistance began in Cochabamba at the Manaco shoe factory where workers accompanied by their families began to organize marches and barricades. That afternoon the campesinos joined the workers due to the increase of taxes the government had proposed (Lavaud, 1986). The campesinos of the outskirt villages began to massively mobilize as well. Between January $24^{\text {th }}$ and $30^{\text {th }}$ about 20,000 campesinos blocked the major highways leading to the commercial areas of Chapare and Santa Cruz (Rivera Cusicanqui, 1984). The build-up prior to event known as "The Massacre of Tolata" took place at the Upper Valley of Tolata which was the center of the campesino mobilization. There was an assumption that the campesinos had kidnapped one of the military mediators, which justified a military attack consisting of three T-33 combat planes used to destroy the campesino blockade (Antezana Ergueta, 1994). The military assault also included a combination of automatic weapons, tanks, artillery, helicopters and fighter planes. A Rangers platoon was use for the military raid that resulted in the killing of thirteen campesinos but the Justice and Peace Commission estimated 
over seventy and five missing (Lavaud, 1986). Some reports revealed brutal descriptions of mounds of corpses and of dead campesinos stacked up like wood (Dunkerley, 1984).

The Banzer regime survived several coup plots leading to a self-coup that gave Banzer full control of the government. Besides the COB and FSTMB that were banned from government activities and under close surveillance, university student organizations began to mobilize and form alliances with other opposition groups. By 1976 the miners resurfaced after several clandestine meetings. The government's attempt to repress a revitalized FSTMB provoked a series of strikes for over four weeks between May and June. The miner's success was dependent on the level of support they received from the urban university students and factory workers and the notice of Torres' assassination while in exile in Argentina boosted their mobilization as protests began to escalate in urban areas (Roddick \& van Niekerk, 1989). By 1977, Banzer called for elections as his regime was experiencing several challenges from all directions, including from the U.S. due to Carter's focus on human rights.

The fall of the Banzer era began in December when four women accompanied by their children began a hunger strike in the La Paz Cathedral alongside the Presidential Palace. They were the wives of imprisoned miners who demanded the unrestricted amnesty, resumption of trade union activity, the return of fired workers, and the withdrawal of the troops from the mines. On December 31, a second group formed by university students and the Union de Mujeres de Bolivia (UMBO) began to fast at the offices of the newspaper Presencia, replacing the wives' children who had become ill and from that point on the strike spread rapidly in all the countries' major cities (Dunkerley, 1984). Initially the hunger strike appeared to be no different from the ones in the past but due to the political turmoil they grabbed the center of national attention and grew into a mass movement. After 10 days there were no longer four women and fourteen children but over one thousand workers and students that were part of the hunger strike (Galeano, 1971). The regime put the armed forces in a state of emergency and demanded all public employees to participate in a mandatory demonstration to counter the hunger strike. By the first weeks of January the group expanded as the family members of political prisoners, exiled activist, and clandestine union organizations joined in (Kohl et al., 2011). Ex-president, Adolfo Siles Salinas, became the strikers' main mediator as they used hospitals, union headquarters and the offices of the archdiocesan newspaper, Presencia, but mostly churches were used to give a religious dimension to the cause (Klaiber, 1998). On the $16^{\text {th }}$ the government issued a lockout and the police forbade the movement of vehicles 
in the major cities of the country. The next day police raided a number of sites occupied by the strikers including the offices of Presencia. As a response the protesters and their allies began singing "Viva mi patria Bolivia", the police left while ambulances took the prisoner to the clinics (Dunkerly 1984, 241). On January $18^{\text {th }}$, Banzer gave in to the demands with the exception of removing his troops from the mines but the momentum did not stop as all of the frustrations held by the Banzerato burst out and literally overwhelmed the regime (Malloy \& Gamarra, 1988). After seven years in power, Banzer was out of office by June of that year. The hunger strike was the most important form of resistance that contributed to the end of the Banzerato.

\section{The García Meza dictatorship: The land of the coup d'état and the narco dictatorship}

In 1977 after international criticism and domestic pressures Banzer called for democratic elections scheduled for mid-1978. Banzer's candidate, General Juan Pereda, was declared the winner even though international monitors found irregularities and determined that the elections were rigged. As soon as the Pereda government was installed, more than 100 people were arrested and the military was sent to the Yungas killing several campesinos that were protesting the coup (Ladman, 1982). Civil resistance was widespread on all fronts from labor, campesino unions, political parties and students. In November, the UDP called for a mass mobilization in demand of fair elections which gave General David Padilla the opportunity to stage a well-planned coup (Dunkerley, 1984). The fear of a growing and organized civilian militancy pushed the Padilla to call for elections on July 1 of 1979. The July elections did not indicate a majority winner, resulting in the ad interim presidency of Walter Guevara Arze. On November 1 of 1979, Coronel Natusch ousted Guevara Arze in a coup known as "The Massacre of All Saints Day." Tanker commands and heavy armed military vehicles began occupying the streets of La Paz while civilians constructed barricades using cobblestones. Coronel Natusch declared Congress illegal as demonstrators surrounded parliament to protect it from military attacks. As a response to the violent coup, the COB in alliance with the CSUTCB (Unified Syndical Confederation of Rural Workers of Bolivia) paralyzed the entire country in a succession of strikes in 24-hour intervals (Roddick \& van Niekerk, 1989). Using their efficient method of resistance, the CSUTCB called for a massive national roadblock movement that lasted two weeks, ending Natusch's sixteen-day regime (Rivera Cusicanqui, 1984). Most of the violence took place in La Paz and at the end of the Natusch 
regime there were over 200 deaths, 125 people were declared 'disappeared' and over 200 injured (Dunkeley 1984, 267).

Congress chose Lidia Gueiler Tejada to head the ad interim government and place the country back on the path to democracy. Gueiler was pressured by the IMF to implement economic reforms which were rejected with civil resistance. Protests were staged by a series of organizations of civil society such as unions, civic groups, and professional associations, which all bypassed Congress to directly pressure the president (Malloy \& Gamarra, 1988). By the second week of December the country was paralyzed due to the successful blockade of the major highways by campesino groups from all regions (Rivera Cusicanqui, 1984). The climate of civil resistance and the election of the leftist Siles Zuazo was used as an excuse for the military to take over the country in one of the most notorious coups in Bolivian history the "Cocaine Coup." The ruthless military coup of General Luis García Meza was reported to have been financed by narcotraficantes and orchestrated by European mercenaries recruited by Klaus Barbie a former ex-Nazi SS officer who was placed in Bolivia with the aid of the CIA (Cockburn \& St. Clair, 1999). A few months before the coup the country was already in a state of terror as military and paramilitary groups linked to the golpistas initiated a wave of violence that intimidated and took the lives of prominent human right advocates, leftist intellectuals and innocent civilians. One of the victims was Father Espinal, who had participated in the hunger strike that contributed to the ousting of Banzer and was a harsh critic of the military. On the day of his funeral 70,000 people turned out on the streets of La Paz to protests against the unjust and brutal assassination of Father Espinal (Ladman, 1982).

General García Meza began the coup in the morning of July 17, 1980 and included the involvement of a paramilitary force led by his Minister of Domestic Affairs, Coronel Arce Gomez. The selective targeting of individual demonstrated that the golpistas understood the power these activists had to gather the masses in civil resistance, but the violence enacted by the paramilitary forces did not deter mass protests against the coup. The miners, not for the first time, were the last to surrender to the García coup. Once the cities were military controlled, paramilitary and regular army units moved into the mines to crush the miner's resistance. After the use of planes, helicopters, tanks and a ranger regiment the mines fells into the hands of the military at the cost of many lives on both sides (García Linera et al., 2004).

The violence continued as union leaders and leftist politicians were either jailed, exiled, or forced to keep in hiding. To add more fear, Arce Gomez warned people to literally walk with their wills under their arm, saying that there would 
be no mercy for those who opposed the regime (De Mesa et al., 2003). There were major strikes in the following months as western human rights organization began to pressure García Meza to step down. It was not until the airing of the "60 Minutes" special titled "The Minister of Cocaine" that the García Meza regime started to crumble. To save face, García Meza fired Arce Gomez and other military officers connected to the drug cartels. The García Meza regime was collapsing due to international and domestic pressures. In May, there was another 24-hour general strike in most of the important mines and in July there was a general strike in Santa Cruz followed by a 24-hour strike in the Huanuni mines (Alexander, 2005). The growing unrest of the masses and the fear of a civil revolution pushed the military to expel García Meza.

General Torrelio Villa took control of the country after García Meza's resignation, and immediately met with civil resistance. Between November 1981 and February 1982, unions were able to mobilize in a series of strikes which had initialed in the Huanuni mines, but by December had reached to urban centers gathering thousands of hunger strikers (Roddick \& van Niekerk, 1989). Torrelio Villa was pushed by the IMF to implement austerity packages that included currency devaluation and labor subsidies. Labor resistance continued in March as the COB again called for a general strike gathering an estimated crowd of 10,000 in Cochabamba alone, but the demonstration was attacked by paramilitary groups killing six people (Alexander, 2005). On May Day over 40,000 people marched in the streets as a clear sign of the restoration of the COB's position, but the military government continued to reject any type of negotiation (Dunkerley, 1984). In July the COB organized a series of "hunger marches" in the country's major cities, in protest against the government's economic policies and called for the reestablishment of a civilian regime on the basis of the elections of 1980 (Alexander, 2005). On July $21^{\text {st }}$, Torrelio Villa was replaced by General Guido Vildoso Calderon, who was chosen by the high command to lead the country towards democracy. In the first week of September students began to block the streets of La Paz on a daily basis; the MIR held a hunger march that attracted tens of thousands and the COB was able to mobilize over 100,000 people demanding political change and an end of military rule (Dunkerley, 1984). The massive waves of civil resistance forced the general to step down and subsequently, Siles Zuazo assumed the presidency on October 10, 1982, ending Bolivia's dark era of military rule. 


\section{CONCLUSION}

Though there were some setbacks, the people of Bolivia were overall successful in the implementation of civil resistance during military dictatorships. There were several forms of civil resistance that were used to include strikes, marches, protests, hunger strike and roadblocks. But the most successful civil resistance campaigns were the ones that were well organized, had a nationwide coordination, received intense media coverage and led to massive participation from all sectors. Some of the outcomes of civil resistance were the delay and sometimes rejection of unfair economic policies, the release of political prisoners, and the ousting of military dictators. The use of civil resistance has been undervalued even though it has played a crucial role in achieving social-political change throughout history. The nonviolent methods of civil resistance had better outcomes compared to violent forms of resistance, such as guerrillas or armed militias. Most importantly, civil resistance contributed to form strong democratic alliances among all sectors and pushed for the re-democratization of Bolivia.

Once in power, the military regime of General Barrientos began to target union leaders, $\mathrm{COB}$ officials, and leftist politicians driving them underground and into exile. Civil resistance was well organized among the militant miners, and it was for this reason that the Barrientos regime focused its attacks on their centers. The San Juan Massacre was indeed a preemptive attack of the Barrientos' regime against the miners who were meeting to resolve how to aid Che Guervara's guerrillas with food and medicine. Barrientos' strategy to separate the mining class from the campesino had worked since campesino organizations blamed the miners' agitation and communist support for the Massacre of San Juan. Barrientos was aware of the strength of people power and was able to convince the campesino leadership to sign "the Military-Campesino Pact." But Barrientos did not have the full support of all campesino groups. Campesinos from the highlands formed the Independent Block of Campesinos to successfully reject his impuesto único tax decree through the use of roadblocks and alliances with labor and university students. The Barrientos regime was much more challenged by civil resistance than by armed insurgencies. As mentioned by Schock (2015, p. 137), state repression can be used to justify "national security" or "combating terrorism," while nonviolent resistance can promote regime defection among security forces through moral and psychological pressure, as well as contributing to shifts in power relations in favor of the nonviolent group. As described by Viezzer (1978), a female miner activist Domitila Chungara mentioned that the miners were aware they needed the support of the people to create revolutionary change and that this 
change would not happen overnight, and it would have never occurred with the use of weapons.

The death of Barrientos provided a brief opportunity to guide the country back to its revolutionary path but even though Torres had the support of the workers, students, and some members of the military, they were unable to stop the Banzer coup. The Banzer dictatorship also called Banzerato (1971-1978) began by targeting his political rivals and opposition to his regime. Banzer also attacked the press and many journalists were imprisoned or exiled. The Banzer regime faced civil resistance with road blockades from the rural sector and with labor strikes from the urban sector. All these groups were brutally repressed and the Massacre of Tolata ended the Military-Campesino Pact. The final blow to the Banzar regime was the successful 1977 hunger strike organized by the wives of imprisoned miners. Their commitment to this nonviolent protest inspired other groups to join the hunger strikes, which grew to over one thousand people. By early 1978, due to the public pressure, Banzer declared a general amnesty for all political prisoners and exiles and announced that he would step down after the elections of July.

The return of the exiles, union leaders, and activists that were underground had an immediate impact on the Bolivian political arena. Ad interim military governments were unstable and civilian governments were weak. The country faced a series of violent military coups and state repression such as the "All Saints Day Massacre," which was challenged by civil resistance. Even the civilian Guiler government faced social unrest since the reemergence of rural mass mobilization reached a high point not seen during any post-revolution military regime. The repressive regime of General García Meza tried to stop the momentum of the people power movements. The mining centers, radio stations, and even Catholic priests were all persecuted by the García Meza regime. The military violence inflicted on the population created a wave of military desertions as officers ended-up shooting soldiers that refused to fire at unarmed protesters. Because of the level of brutality even within its own ranks, the García Meza regime was increasingly isolated both nationally and internationally. Finally, under pressure from the generals of the decaying armed forces and their concern over the unrest, García Meza left office and was replaced by a military junta. The last years of the military regime were affected by its connection to drug cartels, excessive use of violence and corruption. Civil resistance in the form of mass protests from all sectors contributed to the fall of the military government and the reinstallation of a democratic state in Bolivia. The struggle for democracy would finally come after years of delaying the democratization process. 
The constant nonviolent rejection of military regimes by the Bolivian people has demonstrated the power of organized civil resistance. There was no main protagonist but a collective force that included several workers' unions, campesino groups, student organizations, political leaders, and civil activists. Violent state repression against nonviolent protestors backfired and created more public support and, in some case, even direct involvement to their cause. As highlighted by Roberts (2009), nonviolent or civil resistance often generates a condition in which major powers such as the state is publicly shamed for using military force. As demonstrated in this study, the violent use of force by the Bolivian military and paramilitary groups led not only to division among regime supporters but also public sympathy, support and even participation with the civil action groups. Vinthagen (2015) also highlights that nonviolence cannot thrive in the absence of violence because it needs to engage with certain aspects of violence. Despite the brutality and violence used by the Bolivian military, the unarmed protesters maintained the level of nonviolent discipline restraining themselves from violently confronting the army, thus gaining more public support that began condemning the violence of the military regimes. People power campaigns politically empowered marginalized populations and created alliances between urban workers, rural campesinos groups, political leaders and activists. Bolivia's common people joined the wider collective struggle against the unpopular military dictators and demanded the re-democratization of the country.

\section{REFERENCES}

Alexander, R. J. (2005). A history of organized labor in Bolivia. Praeger.

Antezana Ergueta, L. (1994). Las grandes masacres y levantamientos indígenas en la historia de Bolivia (1850-1975). Juventud.

Carter, A. (2012). People power and political change: Key issues and concepts. Routledge Press. https://doi.org/10.4324/9780203181102

Cockburn, A., \& St. Clair, J. (1999). Whiteout: The CIA, drugs and the press. Verso.

De Mesa, J., Gisbert, T., \& Mesa Gisbert, C. D. (2003). Historia de Bolivia. Gisbert.

Delgado González, T. (1984). 100 años de lucha obrera en Bolivia. ISLA.

Della Porta, D. (2002). Comparative politics and social movements. In B. Klandermans and S. Staggenborg (Eds.), Methods of social movement research (pp. 286-313). University of Minnesota Press.

Dunkerley, J. (1984). Rebellion in the veins: Political struggle in Bolivia, 1952-1982. Verso.

Galeano, E. (1971). Las venas abiertas de América Latina. La Casa de las Americas.

García Linera, Á., Chávez León, M., \& Costas Monje. P. (2004). Sociología de los movimientos sociales en Bolivia: Estructura de movilización, repertorios culturales y acción política. Plural. 
Guevara, E. ("Che”). (1994). The Bolivian diary of Ernesto Che Guevara. Pathfinder Press.

Hahn, D. R. (1992). The divided word of the Bolivian Andes: A structural view of domination and resistance. Crane Russak.

Klaiber, J. (1998). The church, dictatorships and democracy in Latin America. Wipf \& Stock.

Klein, H. S. (2003). A concise history of Bolivia. Cambridge University.

Kohl, B., Farthing, L., \& Muruchi, F. (2011). From the mines to the street: A Bolivian activist's life. University of Texas Press. https://doi.org/10.7560/723962

Ladman, J. R. (1982). The Failure to Redemocratize. In J. R. Ladman (Ed.), Modern-day Bolivia: Legacy of the revolution and the prospects for the future (pp. 345-370). Center for Latin American Studies, Arizona State University.

Lavaud, J. P. (1986). Los campesinos frente al Estado. In F. Calderón \& J. Dadler (Eds.), Bolivia: La fuerza historica del campesinado (pp. 277-312). CERES.

Lehman, K. D. (1999). Bolivia and the United States: A limited partnership. University of Georgia Press.

Malloy J. M., \& Gamarra, E. (1988). Revolution and reaction: Bolivia, 1964-1985. Transaction Book.

Martin, B. (2007). Justice ignited: The dynamics of backfire.: Rowman \& Littlefield.

Mitchell, C. (1977). The legacy of populism in Bolivia: From MNR to military rule. Praeger.

Nash, J. (1979). We eat the mines and the mines eat us: Dependency and exploitation in Bolivian tin mines. Columbia University Press.

Payne, F. R. (2012). They make us dangerous (Bolivia 1964-1980). Xibris Corporation.

Quiroga Santa Cruz, M. (1973). El saqueo de Bolivia. Puerta del Sol.

Rivera Cusicanqui, S. (1984). Oprimidos pero no vencidos. Hisbol; CSUTCB.

Roberts, A. (2009). Introduction. In A. Roberts \& T. Garton Ash (Eds.), Civil resistance and power politics: The experience of non-violent action from Gandhi to the present (pp. 1-24). Oxford University Press.

Roddick, J., \& van Niekerk, N. (1989). The Bolivian labour movement. In J. Carriere, N. Haworth \& J. Roddick (Eds.). The state, industrial relations and the labour movement in Latin America (Volume 1, pp. 128-177). St Martin's Press. https://doi.org/10.1007/978-1-34905905-8_5

Rojas Ramírez, P. (1989). Historia de levantamientos indigenas en Bolivia 1781-1985. Ideas Unidas.

Schock, K. (2005). Unarmed insurrections: People power movements in nondemocracies. University of Minnesota Press.

Schock, K. (2015). Civil resistance today. Polity Pres.

Sharp, G. (1990). Civilian-based defense: A post-military weapons system. Princeton University Press.

Tilly, C. (1984). Big structures, large processes, huge comparisons. Russell Sage Foundation

Viezzer, M. (1978). "Si me permiten hablar...": Testimonio de Domitila, una mujer de las minas de Bolivia. Siglo XXI.

Vinthagen, S. (2015). A theory of nonviolent action: How civil resistance works. Zed Books. https://doi.org/10.5040/9781350251212

Zunes, S. (1994). Unarmed insurrections against authoritarian governments in the Third World: A new kinds of revolution. Third World Quarterly, 15(3), 403-426. https://doi.org/10.1080/01436599408420388 